\title{
Experiences of Mothers Who Care for Adults with Profound Intellectual Disabilities. Qualitative Study
}

\author{
Diana Aksamit ${ }^{1}$ and Maria del Mar Badia Martin ${ }^{2}$ \\ 1The Maria Grzegorzewska University, Poland \\ ${ }^{2}$ Universitat Autònoma de Barcelona, Spain
}

HOW TO CITE:

Aksamit, D.,

Mar Badia Martin, M. (2021).

Experiences of Mothers Who Care

for Adults with Profound Intellectual

Disabilities. Qualitative Study.

International Journal

of Special Education, 36(2), 1-12

CORRESPONDING AUTHOR:

Diana Aksamit;

daksamit@aps.edu.pl

DOI:

https://doi.org/10.52291/ijse.2021.36.13

\section{COPYRIGHT STATEMENT:}

Copyright: () 2021 Authors.

Open access publication under the terms and conditions

of the Creative Commons

Attribution (CC BY)

license (http://creativecommons.

org/licenses/by/4.0/).

\begin{abstract}
:
The purpose of this qualitative study was to evaluate the motherhood experience when caring for adult children with profound intellectual disabilities. The study was conducted in Poland with a group of 34 mothers. Data was collected and the qualitative methodology was applied, using in-depth narrative interviews. The results of the research indicated that these experiences also include various critical events; experiences that became part of the motherhood to which the women attributed personal meaning. The study results suggest the need for state reform measures to support mothers of adults with profound intellectual disabilities and at the same time, for many families.
\end{abstract}




\section{INTRODUCTION}

The motherhood of a child with a disability is an area of research interest in Poland (Budrowska, 2001; Karwowska, 2007) and abroad (Al-Kuwari, 2007; Jordan \& Linden, 2013). Mothering an adult with profound intellectual disabilities is, however, infrequently studied in Poland (Aksamit, 2019; Obuchowska, 2008), and worldwide (Gauthier-Boudreault et al., 2017; Redmond \& Richardson, 2003). This is in part due to the small number of people with profound intellectual disabilities worldwide who make up only $5 \%$ of all people with intellectual disabilities (Arvio \& Sillanpää, 2003). Another reason is that motherhood is a particularly challenging, personal, and intimate experience that mothers do not always want to share with a stranger or with a researcher. The situation of mothers of children with profound intellectual disabilities requires them to devote a lot of time, energy, physical and mental strength to the entire process of raising children. This is often related to the fact that they cannot take up employment, which is due to their child's illness and the need to look after the child (Zhu, 2016). This applies to areas of life such as professional activity, hobbies, investing in personal appearance, sexuality, using the services of various educational and care institutions (Luijkx et al., 2017; Mencap, 2001).

The roles and responsibilities of fathers and mothers are distinct in Poland (Imbierowicz, 2012; Titkow, 2012). In social terms, men have a lot of freedom in fulfilling the paternal role as compared to mothers. Women are required to sacrifice themselves, putting their children above their life plans. This is the result of the traditional, conservative Polish model of motherhood (Titkow, 2007). The image of femininity, rooted in Polish culture, has lived by this model. For years it has been an imposed way of self-identification of women - motherhood is the centre of femininity. This model has determined the psychological way of defining the "self" by drawing a clear allocation of household duties as a woman; a nurse, the guardian of the hearth, versus the man in the role of one who works and earns, goes out to people and represents the family (Hryciuk \& Korolczuk, 2012). After 2002, in Poland, the phrase: "assertive woman" appeared, which partially changed the cultural image of the Polish mother (Titkow, 2012). Women began to recognise their right to self-determination and fight for it. They challenged the beliefs underlying the historic figure of the Polish mother. They understand that, without her dedication, her family would not have made it; that she carries a lot of weight on her shoulders. Mothers began to understand that they had the right to say no and did not have to do or be what others wanted (2012). As the years passed, research was showing the potential of women to achieve being able to cope with a myriad of roles, not only as mothers but also as employees or managers (Keleher \& Franklin, 2007; Kinser, 2010), and it began to suggest that the archetype of the Polish mother had become an inappropriate mod$\mathrm{el}$ in the current Polish social and cultural environment (Hryciuk \& Korolczuk, 2012). Nowadays, however, in a world striving for democracy and gender equality, the historic Polish mother figure should be redefined, taking into account new social conditions, and changing cultural contexts.

\section{Motherhood Among Women Raising an Adult Child with Profound Intellectual Disability}

Due to the lack of specialised daycare facilities and permanent residence facilities for the group of people with disabilities, and especially for adults in Poland, women are still with the responsibility of providing a home for adults with profound intellectual disabilities over the age of 25 (the age limit for social service system activities for people with PIMD). There are too few education and rehabilitation centres offering support for people with PIMD and thus for their carers (Aksamit, 2019). It should be noted that in smaller towns or villages, such support does not exist at all. In Poland, many mothers of adults with profound intellectual disabilities are still deprived of formal support from the State for themselves and their children. This also applies to the area of understanding and supporting motherhood as a social and individual construct. Despite many changes in the understanding of motherhood (Wallbank, 2018) and femininity in the last 30 years in Poland, these changes do not apply to mothers of adults with profound intellectual disabilities (Aksamit, 2019).

There are efforts to create a civil society in Poland, but there are still tendencies to reduce selected groups of women to gender stereotypes (Titkow et al., 2004) - which, in the case of women with children with profound disabilities, intensifies with the child's age (Chen et al., 2001; Ferguson et al., 1988). There are social welfare institutions in Poland that, according to legal provisions, are supposed to support people with disabilities and their families, but they are not always available in practical terms to adults with profound intellectual disabilities and their carers. Social welfare institutions for people with disabilities are not widely available, and no mechanism automatically triggers the reaction of these 
institutions if a person is in trouble. Potential recipients must actively ask for and seek support, and the state appears unwilling to meet the need. Although according to the authorities, many institutions are obliged to provide support, there is no mechanism to effectively control and evaluate this assistance. Mothers of adults with profound intellectual disabilities are advocates for their children, but to receive the support they need, many conditions must first be met. These include not being professionally active; having housing conditions as required in the laws and regulations to receive social welfare benefits; timely submission of properly completed forms. Exceeding the monthly income limit may deprive the family of the benefit entitlement, which is a certain and permanent source of income and, thus, critically important. Women, as such, do not want to take the risk of seeking a job because they may lose their benefits. These income-limited requirements force mothers to choose a lower social and economic status because they want to maintain the financial certainty and continuity that allows them and their children, often adults, to survive. All these issues also influence the meaning that women give to their motherhood and themselves as women, mothers, daughters, friends, and other individual roles (Mencap, 2001).

The purpose of this study was to describe, using a biographical method within the context of qualitative research, various aspects of motherhood for mothers of adults with profound intellectual disabilities. The interviews were conducted using a theoretical-methodological approach developed in Fritz Schütze's biographical sociology (1977, 2012). Respondents were asked the question: "How does it feel to be the mother of an adult with a profound intellectual disability?" The experiences of these women (i.e., their past, present and expectations, and thoughts about the future - all in a biographical sense) were examined.

\section{METHODS}

\section{Participants}

There were 34 interviews conducted with mothers caring for adults with profound intellectual disabilities from all parts of Poland. The criterion for selecting respondents was the legal situation of the child (certificate of degree of dependence and previous certificates on the need for education and rehabilitation activities in which the profound degree of intellectual disability was indicated); age (25 years of age); and education (completed broadly defined education provided by the Ministry of National Education). Every interviewee signed consent to participate in the study and was informed that she was free to withdraw from the study at any time. A convenient time and place for the interview were agreed upon. Mothers who were interviewed were between 55 and 78 years of age. Most $(\mathrm{n}=30$ out of $\mathrm{n}=34)$ were single, while $(\mathrm{n}=4)$ were married and shared childcare duties with their husbands. The majority of women ( $n=22$ out of $n=34)$ had secondary education, and $(n=12)$ women had attended higher education. Most mothers $(n=27)$ were not working professionally $(\mathrm{n}=21)$ and did not undertake any professional activity after the child's birth, $(\mathrm{n}=6$ tried to combine a professional career with childcare but after a number of difficult situations abandoned that effort). The women were from different regions of Poland, including urban $(\mathrm{n}=17)$, small towns $(\mathrm{n}=10)$, and rural settings $(\mathrm{n}=7)$.

\section{Procedure}

Our task was to get to know and understand their motherhood experience and the meanings given to it. This approach is related to phenomenology and its creator, Edmund Husserl, introduced the notion of (Latin) ep$o c h$. As understood by the author, it is a departure from judgments or evaluations. This approach requires the researcher to abandon the natural attitude, transcendental reduction (Råheim et al., 2016). In phenomenology, reflection is paramount. The researcher sets himself the task of reconstructing the experiences of the individual understudy through the use of reflection. Here, we have a transition from theoretical reality to everyday reality until the researcher's reflection on his or her life occurs. The nature of the study required direct contact with the respondents and involvement in the interview.

Recruitment: Fifteen of the mothers were informed about the research by their service provider (i.e.: municipal social service employees, doctors, or nurses). Some adults with profound intellectual disabilities, after completing their education, were offered a place in a daycare centre and their mothers were informed by trainers, therapists, and psychologists providing various therapy-related supports. The other ten mothers were recruited using the snowball sampling method (Emmel, 2013; Rubin \& Babbie, 2010).

Interviews: The study was conducted in Poland from October 2016 to January 2018 in Polish. Most of the interviews $(n=29)$ took place in the interviewees' homes, others $(n=5)$ occurred at places and times designated by the participant. Before an interview, each interviewee was informed that she was free to interrupt the interview at any time, though none of them did so. The interviews lasted from 90 to 240 minutes. A narrative interview 
process was used (Schütze, 2012), which is similar to an in-depth, free conversation and consisted of three parts:

1. The main phase of the narrative - presenting the research purpose to a respondent and discussing ethical issues (e.g., that information from the research is anonymous and confidential, and that results will be used only for scientific purposes). At that point, one key question was asked: "What is it like to be a mother?"

2. The next phase of questioning was aimed at asking about topics which the researchers wanted to develop. There were also questions relevant from the perspective of the research assumptions, which were not addressed by the women. In this section, the researchers were tasked with arranging the story chronologically. The respondent was asked to complete the unclear parts, add missing phases, or solve contradictions.

3. Balancing phase: The narrator's comments on the interview (Hermanns, 1987; Prawda, 1989). The researchers' task was to ensure that women talked about their individual experiences and not in general. The interviews were recorded using a voice recorder, transcribed, repeatedly listened to, and continuously juxtaposed. The interview data was encoded using Atlas-ti (version 8), a qualitative data analysis software package. Each interviewee was given a fictitious name to maintain personal data confidentiality.

\section{The Application of Theoretical-Methodological Con- cepts in the Research on Motherhood}

Fritz Schütze's theory and methodological approach $(1977,2012)$ created a theoretical framework and allowed for the study of motherhood from a biographical perspective: past - present - future. This made it possible to understand the subjective experience of the phenomenon being studied. Narrative interview styles may yield material that allows to reconstruct the pattern of individual biographical experiences and to discover the basic structures of the process of biographical experience, corresponding to the variants of the narrator's attitude towards the phases of her life (Barthes, 2004). A method of continuous comparison has been used to analyse the data, looking for another participant's narrative that would enable questions to be answered (Charmaz, 2006). Comparing fragments of interviews repeatedly made it possible to conclude that the category was saturated (i.e., there was a moment when the next interview did not bring anything new to the research) (Auerbach $\&$ Silverstein, 2003). Qualitative research needs to be designed to ensure objectivity, accuracy, and reliability of data (O’Reilly \& Parker, 2013). Therefore, multiple credibility checks were performed to assess the thoroughness of the interviews to safeguard and ensure that the data was reliable. The reliability and accuracy of the data were assured by:

1. Continuous comparison of the cases studied. This methodological procedure allowed the conclusion that the examined category was saturated - there was a moment when the next interview did not bring anything new to the study (Dwyer \& Buckle, 2002). This marked the end of the study.

2. Applying the principle of in-depth analysis of each word - the recordings were studied several times and the answers were juxtaposed many times. The credibility of the data was ensured by transcribing the recordings, which is especially important.

3. Authorisation of the interview by interviewee; the respondents were asked to verify the truthfulness of the recorded reflections (O'Brien et al., 2014). Each of the interviewees agreed with our interpretation of the data, that it was not an over-interpretation, and that it represented authentic patterns of the motherhood experience by Polish women raising adults with profound intellectual disabilities.

\section{RESULTS}

Analysing the interviews, an attempt was made to understand the multidimensional experience of the interviewees. To illustrate the subjective meaning the respondents gave to their motherhood, the results of the analysis of the interview data were divided into two main emergent themes: effects of cultural background and traditions and social system inadequacy to meet the needs of a mother raising a child, adolescent, or adult with profound intellectual disabilities. Mothers of adults with profound intellectual disabilities illustrated a variant model of motherhood in Poland. On the one hand, this model fits into the cultural figure of the Polish mother (a woman eager to sacrifice a lot), a heroic woman; but on the other hand, it is a model of a heroine who breaks cultural and social stereotypes.

\section{The Effects of Cultural Background in the Context of the Meanings Ascribed to Motherhood}

Respondents pointed to various cultural factors and traditions that were imposed on the role of the mother of a person with profound intellectual disabilities. They emphasised that, in Polish society, giving birth to a child with disabilities means that a woman must sacrifice re- 
gardless of the individual needs of the mother. Reference to the mother figure in traditional Polish culture was present in most interviews. The women pointed to the difficulties that made it impossible for them to meet this model for many years. They pointed out that they had to negotiate their social position not only as mothers but also as women. Planning a public space should consider the needs of all users.

Mother: People don't understand that I need an ordinary conversation and not repeating questions about how Janek is doing, how I'm doing. I am sorry but when is someone going to ask how I am feeling? I didn't want and don't want any closer contacts: "good morning" and "goodbye", sometimes to talk for a while. [Hanna]

Mother: None of us need mercy. Maybe in the past but not now. A mother like me only needs understanding, normality. A long time ago I stopped trying to make someone like me, to make someone accept my child. Forget it, I won't ask anymore. [Jadwiga]

The age of the respondents was one of the main factors why the interlocutors were unable to cope with the cultural requirements of mothers. As they were aging, these mothers noticed that their motherhood was a different model from the one they had commonly known and accepted; from the model, they had been trying to meet for years. The traditional model of motherhood, care, and nursing (i.e., carrying, feeding, etc.), are associated with mothering a small child. It was different for our respondents. As the mothers and their children grew older, there were more caring and nursing activities for children, and they required more mental and physical effort from the aging woman. Confirmation of these observations can be found in other studies in this area (Caples \& Sweeney, 2010; Yoong \& Koritsas, 2012).

Mother: Believe me, I do not have the strength to carry him every day. Sometimes I can't lift him from his wheelchair, sometimes I just pull him through the room. When I was younger, I used to carry my son even up the stairs, I devoted myself entirely; today I am 78 years old, and I can't. In the back of my mind, I always had the idea that I should be the best mother; today I blame myself, I have no strength. [Angelika]

Mother: The reality I had to face required a lot of sacrifices. Everyone said it would be inappropriate. I was ashamed to ask for help because somebody stuck it in my head that it was my child and my business, that since I am a mother, I have to deal with it. Yes!!! Today I'm hunched and I still can't ask for help, because we, mothers of children with disabilities, have already been assigned this task. I pray that someone will finally oppose it. [Malwina]

The interviewees pointed out that in various institutions providing social services in the broadest sense of the word, they were treated as mothers of "eternal children", "little children" regardless of the age of their children (Heller et al., 1997). Many of them said that none of the institutional decision-makers noticed that, due to their age and the age of their children, they were unable to meet the administrative requirements in dealing with formalities due to architectural barriers for wheelchair mobility (e.g., curbs, stairs, no lifts) and rigidly imposed business hours. They also remembered situations in which officials allowed them to express negative opinions about the organisation with regards to time and ways of dealing with various matters by mothers.

Mother: "Come tomorrow at eight o'clock", "go there", and no one had a reflection that I was in a wheelchair with Btaziej in it, he was 14 years old. But nothing has changed. Today I am 70 years old, and I hear again: "Do this, do that". Now the situation is different because I start yelling, recording, threatening that I will come back with journalists. [Patrycja]

Mother: Once they told me to go up to the third floor. So, I left my daughter and said that if she starts screaming, please let her drink and be careful because she can bite. The lady looked at me and said, "but take your child with you, please." So, I said: "Please help me to bring the wheelchair, just be careful and protect your spine because it weighs 120 kilograms". And the situation took a different pace. She went there and arranged it herself and now everyone knows me there. [Julia]

With age, it became more and more difficult for women to take care of a person with a profound intellectual disability. It was dictated, on the one hand, by the fact that caring for an adult person requires a greater expenditure of physical effort: lifting, carrying. On the other hand, the age of the mothers meant that they did not have so much physical strength, they were sick and required care. It is a reality and the image of women is still unknown in Polish society.

\section{Fulfilling the Role of the Mother}

Motherhood understood as a social role incorporates a set of expectations concerning the mother's behaviour 
towards her child, her immediate family, and society (Eisenhower \& Blacher, 2006). The interviewees pointed out that they were constantly haunted by social expectations towards their role as mothers and towards the functioning of their children. Mothers pointed out that the social position of mothers of children with profound intellectual disabilities in Poland is changing very slowly. In their opinion, little has changed with regard to the expectations concerning the role of the mother of a child with disabilities in that it is still expected that she should sacrifice fully in her devotion to her child.

Mother: I wanted to go back to work but everyone, even my mother, said that it wouldn't be appropriate, that I should stay with my child because he was sick. People think that a mother like me should not work, should not travel. I ask, is there anything more? I didn't go back to work, I have become bitter, I have been left alone. I have never left Poland. [Zuzanna]

Mother: I once dreamed of having a child and then, finally, yes, I did! But I didn't want to be a slave to anyone because that's the correct name for that. My husband thought that only I have duties, all the duties. I was everything but at the same time nobody for years. [Hanna]

Mother: It would be best to make a list of what we can and cannot do. Going to the hairdresser's - prohibited; having sex-prohibited; spending money on yourself and not just on the child-evil. It has been like this, and it still is now. It took me some time to tell myself and others that what I do, what kind of mother I am, is only my business. And I have even been happy for years. [Eucja]

The interviewees' statements showed that it took some of them some time to decide to consciously oppose selected aspects of the cultural model related to the role of the mother of a child with a disability. We can see certain connections between women's decisions and the changing socio-cultural conditions in Poland.

Mother: I remember when women went on strike, it was about [child] maintenance. It was in the 1990s. Yes, it was the time when women were no longer frightened. There were a few mothers who activated us all and made us realise that it was high time to stop staying at home. That our children deserve a decent life, but so do we, women. [Agata]

Mother: There was no tolerance for a woman to say: "Sorry, I'm tired" or "Sorry, I'm going to have a beer" or "Sorry, but I need a break". But times have changed.
Mothers started to come out of the shadows. I will tell you this: many of us will cry a lot and a long time will pass before someone starts seeing not only mothers but also the women in us. [Zuzanna]

The respondents often admitted they felt sorry that their lives looked different than they had imagined. This disillusionment was especially true in respect to being a mother and feeling satisfaction from their motherhood. However, they felt competent in their roles as mothers of children with profound intellectual disabilities. They pointed out, however, that by being constantly excluded from different environments, they were not able to fully talk about their problems, their reality, or how they function.

Mother: I am a woman, I am a human being, I am a citizen. I also need to go to the doctor; I also feel like going to the hairdresser or to the store. But often, because of my situation, I can't because I have no one who would stay with my son. [Inga]

Mother: I had friends once, but they had their own lives, and somehow it got blurred. Nobody wanted to take responsibility. It's so strange, you know. On the one hand, everyone offered to help but when the need occurred there weren't many people willing to help. [Hanna]

The most awkward thing in the motherhood of the participants was to find space for themselves. Since they devoted all their time to the rehabilitation of their children with disabilities, they learned to live a lonely life. They also stressed that the older they were, the more difficult loneliness was for them.

Mother: I wanted to get married again. But my mother, my father, my whole family did not want it. They thought that I shouldn't, that no one would be able to love my son. Today I am all alone, sometimes I talk to myself. [Nina]

Mother: It's nothing that she doesn't understand much. I talk to her, shout, explain... Sometimes I talk to myself. Let's be honest, I feel lonely. In the past, when I was younger, it was better; today I'm not only old but also alone. [Inga]

The analysis of the interviewees' statements indicated that women were aware of neglecting themselves and of the difficulties in getting out of their situation. Even when they had an opportunity to devote time to themselves, they could not stop thinking about their child... 
This probably results from the Polish culture of motherhood in which the woman is fully responsible for the child and is obliged to provide the child with the best of everything and what is considered appropriate by society (Hryciuk \& Korolczuk, 2012). These women pointed to many examples of social control and evaluation, social requirements, and expectations concerning raising a child with profound intellectual disabilities.

Mother: The public opinion is that a mother like me should only look after the child. It is not appropriate for me to go on vacation because it will be automatically claimed that I did it using public funds. It's not right for me to be neat, nicely dressed, to have a car. This raises some social objections and internal objections. [Irena]

Mother: It works like that: when I want to buy new shoes for myself, first I think if Zosia has everything. When I buy myself something, I have a guilty conscience. I don't know, this is how it works. If I leave for a while, I want to come back a moment later. Once I left for a few days and my sister stayed with her, I couldn't rest, I kept looking at my phone. [Laura]

Mothers doted their already adult children but ignored their own needs. They believed that their decisions about sacrifice were right. This attitude was a result of the lack of solutions in Poland supporting women bringing up disabled children and taking care of them throughout their lives. Some of the women referred to women's sexual and emotional needs and the need for physical touch.

Mother: I was 32 when I was left alone. I had to forget about my needs. I didn't have sex for years, because of how, with whom. Sometimes a person would like to be hugged by someone, hear something nice. I'll be honest, I dreamt that maybe I will meet someone new with whom I will build a new family. [Julia]

Mother: There was no man in the house. But it wasn't just about sex. I wanted someone who would love me and my child. But it was too difficult for men, in a way I understand them. [Antonina]

The statements of the mothers surveyed show that the quality of care for a person with profound intellectual disabilities consists not only of the mothers' commitment, but also of cultural, social, and political factors. At the same time, the research conducted in a group of mothers of adults with profound intellectual disabilities can become a catalyst for change in thinking about motherhood in relation to a child with disabilities (taking into account not only the profound degree of disability but also other degrees and types of disability).

\section{Inadequate Social and Legal System to the Needs of Mothers and their Children with Severe Intellectual Disabilities}

Legislation often unequally grants support to people with specific degrees of impairment or types of disability (i.e., also to their parents). As mentioned previously, both in Poland and worldwide (Arvio \& Sillanpää, 2003), the group of people with profound intellectual disabilities represents the smallest percentage of the population. The size of the group has an impact on the number of legal acts, models of social support and interest in this issue, as well as on the quality of life of adults with profound intellectual disabilities and their carers (this study pays particular attention to mothers). Respondents' statements concerning the issue of social support systems are presented below, organised around timeframes (past, present, future).

In the 1990s there was legislation in Poland pertaining to the system of support for people with disabilities. This legislation referenced these populations: "disabled", "parent of a person with a disability", and "legal guardian of a person with a disability." However, the level, nature and type of support needed for these groups were not taken into account. This was especially true for mothers of people with severe intellectual disabilities, because their reality was unknown in the social and scientific discourse. This group of mothers was "invisible social beings".

Mother: Nobody knew what to do with our children. It was suggested that they should be admitted to care facilities and the problem of both the child and the mother would be solved. There was no way to support both the child and the woman. The decision was up to us: you wanted to have a child, then stay at home and take care of your child; you want to work, i.e., live like anyone else, give away your child and stop looking for problems. [Stanisława]

Mother: Nobody asked how I felt or if I needed anything. If one of my son's doctors asked about me, it was a miracle. Everyone asked about the child. And me? There was no support for us, none. Nobody knew what I felt, how easily each of us was excluded from life among people. [Klementyna]

In Poland, until 1997, people with profound intellectual disabilities were excluded from compulsory 
schooling, and most of them were placed in institutions. The situation has changed with the enforcement of the Regulation of the Minister of National Education of 30 January 1997 on the Organisation of Revalidation and Education Activities for Children and Young People with Profound Intellectual Disability (Journal of Laws of 1997 No. 14 item 76).

Mother: He had a home education. A teacher came twice. They did not want him at school, well, that's how it was. But no matter what, then I had two days and could sit down for a while, I could take a break. A year passed and he started going to school for 3 days and I started working in the laundry. For those three days, I could be myself, I could go out to people. [Liliana]

Mother: I was surprised when the psychologist and the kindergarten principal asked how I was doing. They gave the contact details of a foundation so that I could meet with other parents. [Celina]

Referring to their present situation, most of the respondents stressed that, in their opinion, not much had changed in Poland for parents or legal guardians of people with profound intellectual disabilities. They emphasised that the number of legal documents meant to support families raising children with disabilities is gradually increasing, but this has no impact on their psychological and emotional situation. This legislation is intended to support mothers of children with profound intellectual disabilities on the one hand, but on the other hand, it puts them in a position to choose whether to receive childcare benefits or to take up a professional career. The choice is difficult because Polish law does not allow for combining these two revenues.

Mother: More than a half-century that I have lived... Everything has changed, thousands of laws, laws that we have all been waiting for. And what is the result? There was no place or mention of our children, of us. We are in a slightly different situation, but I don't know if anyone can see it. I will tell you; nothing has changed for fifty years. Save the fact that now they let our children go to school. But for me as a mother, today sick and old - nothing... [Irena]

Mother: I couldn't work, I couldn't make money. Today the same thing. I feel so sorry for these young mothers. They fight, go to work and their benefits are taken away from them. But women are strong, they will manage that's what they think about us. [Alina]
In Poland, since 2015, the importance of national and cultural traditions has been gradually increasing, which, as the respondents emphasised, further strengthens the conservative image of motherhood, vocation, and obviousness (Titkow, 2012). According to the respondents, they are expected to make sacrifices regardless of their mental condition or personal needs, they are expected to be mothers according to an imposed stereotype. The women emphasised that it is they who are supposed to provide support, not to expect to be helped.

Mother: Now, it is even worse. It is changing in Poland, but for the worse. Much is said and written about the family. But it's not going to do any good. All the time we have a problem thinking about a working, career-oriented mother. A mother is always with a child. Sometimes I have an impression that these young women can feel social pressure - if you don't give birth, you are not a great Polish woman. [Zyta]

Mother: They are introducing respite care, creating some projects. But has anyone asked me if I, if we, need such support? You are the first one to come to my house and see how I live. It is 2019 and I have to carry my son in my arms, I have to ask for money to live because I have been forbidden to work. Someone failed to understand that our children are no different from any other child in Poland. [Helena]

The women's statements revealed their anxiety about the future. This anxiety had two dimensions. Firstly, they were worried about the welfare of their adult child if they, the mothers, passed away first; they were concerned that their child would be left alone or have to go to a state institution such as a nursing home (24-hour care facilities for the elderly, sick and disabled). Secondly, they were anxious about whether they would be able to cope mentally with their child's death and whether they would be able to live alone after the death of their child. They emphasized that, despite many difficult experiences, their motherhood was the meaning of their life.

Mother: I worry every day, I am afraid. I do not know what will happen to him if I pass away. Who is going to hug him? They will feed him and change his nappy, nothing more. I am afraid that if he passes away, I won't be able to live. I am sorry but I cry when I think about it. It is the meaning of my life; he is my life. [Malwina]

Mother: I don't know what is going to happen. I know one thing; I can't live differently. I wanted that one day, I could wake up in the morning, drink coffee, go for a 
walk, lie down in the tub, go somewhere. But it is gone. I want my child to live, and I want to be with him. He keeps me alive. There are many plans regarding our children, that there will be houses, foster homes... but these are plans. [Nina]

None of the respondents were certain of any positive outcomes for the future of an adult with profound intellectual disabilities. Most of them stressed that, despite multiple attempts, they were not able to fully secure their children's future. For them, the future is a source of concern and is seen as something that keeps them alive and 'doesn't let them die.

Mother: I know there is nothing I can do, so I have to live. Maybe the day will come when someone says: "Here you are, this is a centre for you and your son, like a normal home but with support". I cannot die, there is so much I have to do. [Wiktoria]

Mother: It is ridiculous, but I'm not planning to die... If I am, it is only together. [Wanda]

The interviewees indicated that, as they grew older, respondents felt increasing that they needed someone close to them or an institution that could secure the future of their adult children. The narrative showed that with time, there were fewer and fewer other people in the surroundings of these mothers (e.g. close family, relatives, friends) who would take over the mother's duties. Respondents emphasised that the older they and their children were, the shorter the "support chain" was becoming. The women's statements suggested that they lacked these multidimensional supports for most of their lives and that they have had to work extremely hard to secure any help to which they were legally entitled. This is a disadvantage for two reasons: mothers are discouraged from seeking support, and even if it is tailored to their needs, they do not trust it and they stop exercising their rights.

Mother: It cannot be like that - that I should keep asking all the time. For as long as I can remember, I have been asking. I have learned to tell lies. Yes! This is not how it should be. [Ludmiła]

Mother: There is much that each of us has to ask for. Sometimes I feel as if I were extorting money from officials. But I do not spend it on trivial things, and I have to document every penny. [Liliana]

From the statements of mothers of adults with profound intellectual disabilities, it follows that they and their children need universally understood support. According to the respondents, their life experience of motherhood is already a specific source of information support for younger mothers of children with profound intellectual disabilities. The mothers repeatedly stressed that the support provided opens up the possibility of using alternative sources of social support and informal social networks. One of the problems, according to the in-depth analysis of the interviews, was the nature and type of support that was institutionally imposed on women, which they often did not need. According to the respondents, when support is tailored to the actual needs of mothers, then it raises their self-esteem, satisfaction with motherhood makes them more independent and gives them the strength to act. In contrast, support that is not tailored to the mothers' actual needs weakens their psychological functioning.

\section{Motherhood as a Source of Self-Fulfilment}

An analysis of the research suggests that, despite many negative experiences, motherhood has, over the years, become a primary meaning in women's lives, a point of reference in their self-biographies. The interviewees emphasised that motherhood provided meaning to their lives and provided a goal, something that kept them alive, a source of self-confidence, self-fulfilment, and their primary source of joy in life. Some of the mothers even said that this was their mission in life. They took many actions, but it was a struggle for their children's place in the public space. This was one of the elements of motherhood that became the axis of the respondents' self, and they gave it particular significance.

Mother: Nothing matters, only she matters. There was a time when I could not find the meaning of life. I just did not know what the purpose of my life was. But now I know that she is my whole life. I know what I can do best - be a mother. [Sylwia]

Mother: I cannot imagine another life today. I may have wanted to have a different life in the past, but not now. We have to be able to accept our fate. I explain that to young mothers, but everyone has to see for themselves that this child is our miracle, it is the child that makes us so strong. [Rozalia]

Although many studies still focus on the negative aspects, there are also those that show the positive aspects of parenting a child with disabilities: spiritual growth, family harmony, ability to cope with many demanding situations, shared parenting (Ferguson et al., 1988). 
There are also studies describing the nature of the roles of mothers and fathers, taking into account the disability of the child: the process of personal regulation of negative emotions connected with mental strain, ways of managing difficult situations, the influence of the mental health of individual family members on the functioning of the entire system (Goddard et al., 2000).

Mother: I will be honest, sometimes I clench my teeth, sometimes I cry in the bathroom. But I can also look at life differently from all my neighbours. I have learned to make decisions; I have learned to be humble and accept things. [Stanisława]

Mother: This child has taught me many things, first of all, to see beauty in small things, to enjoy every moment. He has taught me to find something good for myself in suffering. It may be strange, but I would not be that rich in spirit today if it were not for my daughter. She is the one who taught me love. [Ksenia]

The analysis of this data suggested that the critical events that occurred were an opportunity for significant life changes. By re-evaluating their challenging experiences, mothers restructured their self which increased their sense of meaning in life.

\section{CONCLUSION}

Studies show that the experiences of mothers caring for adults with profound intellectual disabilities reveal a different model of motherhood not well represented in research or policy. The current research suggests that the traditional model of the Polish mother, which for years has shaped the image of the mother of a child with disabilities, negatively impacts women in these roles. The traditional model of the Polish mother has also translated into expectations for mothers without taking into account the voice of women and their acceptance of this.

Research shows that the current scientific and social discourse takes into account the situation of the mothers of children with different degrees of disability, but it does not attend to the motherhood of ageing women, senile women, and mothers looking after adult children. Thus, there is a need to create a new model of motherhood for this group of mothers, not only in Poland but worldwide. Further theoretical analysis and research are needed to bring about change in this area. This can become a voice for change at the state level in terms of existing solutions to support mothers of adults with profound intellectual disabilities, as well as individuals with profound intellec- tual disabilities themselves. The statements made by these women show the importance that mothers ascribe to motherhood, to femininity, and to the situation in which they find themselves, which has for years been derived from the fact that the existing support system does not take into account their real needs. As indicated by the respondents, it is not entirely about the lack of financial support, as financial support did not solve the problems they experienced; for example, a sense of difference, marital relations, creating their femininity and satisfying or neglecting their own needs. There is a need for the social support system to define the type and nature of support, giving mothers a choice. Tailored help for these women could, on the one hand, support them with their individual emotional and physical challenges; care activities for an adult child (e.g., feeding, carrying, and dealing with problem behaviour).

We can see that over the years the challenging motherhood experienced by these women has become increasingly difficult. Even so, for most of them, it was a source of strength, a point of reference for the self. Thanks to the experience they have had, they are potential support for young mothers who, if the social system does not improve, will have the same types of problems. Therefore, there is a need to continue research in this area, to publicise these issues both in Poland and worldwide so that ageing mothers can have a better quality of life. There is a need for discussion between mothers and state decision-makers in various sectors. Those who are active and responsible for the social system should take on the role of advisers. The system should be flexible to take into account individual situations of mothers and their adult children. Because it is inherent in human contact, taking place in the social space and forming the basis of social life, to wish to establish social relations and to see another participant in this process as an exceptional, unique element (Buber, 1992; Stewart, 2009).

We believe that when the reality of mothers of children and adults with profound intellectual disabilities is known and demonstrated, a chance to anchor a new model of motherhood will emerge. It should be stressed that this new model of motherhood is just being generated by the women we are studying.

\section{Study Limitations and Directions for Future Research} Interpretation of these results must be made with caution for a number of reasons. First, this study examined primarily older women who are mothers of adult children with profound intellectual disabilities. Research should also be carried out with younger mothers of children with 
profound intellectual disabilities to be able to identify individual stages and critical events which have an impact on their biographies. There is also a need to examine the mothers of children and adults in different countries and cultures to be able to draw possible cross-cultural comparisons. We believe that this could provide insights into the women's experiences in highly developed countries where, as we assume, the support system is also at a higher level. The issue of profound intellectual disability should also be addressed in more detail to examine how a particular disability affects the motherhood of women at various stages of the process. Given the applied qualitative research methodology, a weakness may be the influence of the researcher on the subject, as well as the unrepresentative group size.

\section{ACKNOWLEDGMENT}

Many thanks to Michael Wehmeyer from the University of Kansas in the USA for his unstinting support throughout the research project and, in particular, for his insightful comments on this article.

\section{FUNDING}

The authors disclose receipt of the following financial support for the research, authorship, and publication of this article: by the The Maria Grzegorzewska University.

\section{CONFLICT OF INTEREST STATEMENT}

The authors declare that the research was conducted in the absence of any commercial or financial relationships that could be construed as a potential conflict of interest.

\section{REFERENCES}

Aksamit, D. (2019). Kobiety - matki o macierzyństwie. Socjopedagogiczne stadium narracji matek dorosłych osób z niepełnosprawnością. Warsaw: The Maria Grzegorzewska University Press.

Al-Kuwari, M. G. (2007). Psychological health of mothers caring for mentally disabled children in Qatar. Neurosciences, 12(4), 312-317.

Arvio, M., \& Sillanpää, M. (2003). Prevalence, aetiology and comorbidity of severe and profound intellectual disability in Finland. Journal of Intellectual Disability Research, 47, 108-112. https://doi.org/10.1046/j.1365-2788.2003.00447.x

Auerbach, C. F., \& Silverstein, L. B. (2003). Qualitative data: An introduction to coding and analysis. New York University Press.

Barthes, R. (2004). Wstęp do analizy struktury opowiadań. In M. Głowiński (Eds.), Narratologia. Wydawnictwo Słowo/obraz terytoria.

Buber, M. (1992). Ja i Ty. Wybór pism filozoficznych. Warsaw: Instytut Wydawniczy PAX Press.

Budrowska, B. (2001). Regulamin i improwizacje, czyli o kulturowym skrycie bycia matką. Kultura i Społeczeństwo, 2, 105-120.

Caples, M., \& Sweeney, J. (2010). Quality of life: a survey of parents of children/adults with an intellectual disability are availing of respite care. British Journal of Learning Disabilities 39, 64-72. https://doi.org/10.1111/j.1468-3156.2010.00619.x

Charmaz, K. (2006). Constructing grounded theory: practical guide through qualitative analysis. Sage Publications, Inc.

Chen, S. C., Ryan-Henry, S., Heller, T., \& Chen, E. H. (2001). Health status of mothers of adults with intellectual disability. Journal of Intellectual Disability Research, 45, 439-449. https://doi.org/10.1046/j.1365-2788.2001.00352.x

Dwyer, S. C., \& Buckle, J. L. (2002). The space between: On being an insider-outsider in qualitative research. International Journal of Qualitative Methods, 8(1), 54-63. https://doi.org/10.1177/160940690900800105

Eisenhower, A., \& Blacher, J. (2006). Mothers of young adults with intellectual disability: multiple roles, ethnicity and well-being. Journal of Intellectual Disability Research, 50(12), 905-916. https://doi.org/10.1111/j.1365-2788.2006.00913.x

Emmel, N. (2013). Sampling and choosing cases in qualitative research. University of Leeds Press.

Ferguson, P. M., Ferguson, D. L., \& Jones, D. (1988). Generations of hope: Parent perspectives on the transitions of their children with severe retardation from school to adult life. Journal of the Association for Persons with Severe Handicaps, 13, $177-187$. https://doi.org/10.1177/154079698801300308 
Goddard, J. A., Lehr, R., \& Lapadat, J. C. (2000). Parents of Children with Disabilities: Telling a Different Story. Canadian Journal of Counselling 34(4), 273-289.

Gauthier-Boudreault, C., Couture, M., \& Gallagher, F. (2017). How to facilitate transition to adulthood? Innovative solutions from parents of young adults with profound intellectual disability. Journal of Applied Research in Intellectual Disabilities, 31, 215223. https://doi.org/10.1111/jar.12394

Heller, T., Hsieh, K., \& Rowitz, L. (1997). Maternal and paternal care giving of persons with mental retardation across the lifespan. Family Relations, 46, 407-15. https://doi.org/10.2307/585100

Hermanns, H. (1987). Narrative interview - a new tool for sociological field research. Folia Sociologica, 13, 43-56.

Hryciuk, R. E., \& Korolczuk, E. (Eds.). (2012). Pożegnanie z Matką Polką? Dyskursy, praktyki i reprezentacje macierzyństwa we współczesnej Polsce. Warsaw University Press.

Imbierowicz, A. (2012). Matka Polka w defensywie? Przemiany mitu i jego wpływ na sytuację kobiet w polskim społeczeństwie. Ogrody Nauk i Sztuk, 2, 430-442.

Jordan, J., \& Linden, M. A. (2013). 'It's like a problem that doesn't exist': The emotional well-being of mother scaring for a child with brain injury. Brain Injury, 27, 1063-1072. https://doi.org/10.3109/02699052.2013.794962

Journal of Laws. (1997). Regulation of the Minister of National Education of 30 January 1997 on the Terms and Methods of Organisation of Revalidation and Education Activities for Children and Young People with Profound Intellectual Disabilities (Journal of Laws of 1997 no. 14 item 76).

Karwowska, M. (2007). Macierzyństwo wobec dziecka niepełnosprawnego intelektualnie. The Kazimierz Wielki University Press.

Keleher, H., \& Franklin, L. (2007). Changing gendered norms about women and girls at the level of household and community: A review of the evidence. Background paper prepared for Women and Gender Equity Knowledge Network of the WHO Commission on the Social Determinants of Health.

Kinser, A. E. (2010). Motherhood and feminism. Seal Press.

Luijkx, J., Van der Putten, A. A. J., \& Vlaskamp, C. (2017). Time use of parents raising children with severe or profound intellectual and multiple disabilities. Child Care Health and Development, 43(4), 518-526. https://doi.org/10.1111/cch.12446

Mencap. (2001). No ordinary life: The support needs of families caring for children and adults with profound and multiple disabilities. London: Royal Society for Mentally Handicapped Children and Adults.

O’Brien, B. C., Harris, I. B., Beckman, T. J., Reed, D. A., \& Cook, D. A. (2014). Standards for reporting qualitative research: a synthesis of recommendations. Academic Medicine, 89 (9), 1245-1251. https://doi.org/10.1097/ACM.0000000000000388

Obuchowska, I. (2008). Dziecko niepełnosprawne w rodzinie: praca zbiorowa. WSiP.

O'Reilly, M., \& Parker, N. (2013). 'Unsatisfactory Saturation': A critical exploration of the notion of saturated sample sizes in qualitative research. Qualitative Research, 13, 190-197. https://doi.org/10.1177/1468794112446106

Prawda, M. (1989). Biograficzne odtwarzanie rzeczywistości. O koncepcji badań biograficznych Fritza Schütze. Studia Socjologiczne, 115(4), 81-98.

Råheim, M., Magnussen, L. H., Sekse, R. J. T., Lunde, Å., Jacobsen, T., \& Blystad, A. (2016). Researcher-researched relationship in qualitative research: Shifts in positions and researcher vulnerability. International Journal of Qualitative Studies on Health and Well-Being, 11(1), 30996. https://doi.org/10.3402/qhw.v11.30996

Redmond, B., \& Richardson, V. (2003). Just getting on with it: exploring the service needs of mothers who Take care for young children with severe/profound and life threating intellectual disability. Journal of Applied Research in Intellectual Disabilities, 16 , 205-218. https://doi.org/10.1046/j.1468-3148.2003.00165.x

Rubin, A., \& Babbie, E. (2010). Essential research methods for social works. Brooks/Cole.

Schütze, F. (1977). Die Technik des narrativen Interviews in Interaktionsfeld-studien - dargestellt an einem Projekt zur Erforschung von kommunalen Machtstrukturen. Bielefeld University Press.

Schütze, F. (2012). Analiza biograficzna ugruntowana empirycznie w autobiograficznym wywiadzie narracyjnym. Jak analizować autobiograficzne wywiady narracyjne. In K. Kaźmierska (Eds.), Metoda biograficzna w socjologii (pp. 141-278). Wydawnictwo Nomos.

Stewart, J. (2009). Wprowadzenie do komunikacji interpersonalnej. In J. Stewart (Eds.), Mosty zamiast murów. Podręcznik komunikacji interpersonalnej (pp. 35-59). Wydawnictwo Naukowe PWN.

Titkow, A. (2007). Tożsamość polskich kobiet. Ciągłość, zmiana, konteksty. Wydawnictwo IFiS PAN.

Titkow, A. (2012). Figura Matki Polki. Proba demitologizacji. In R.E. Hryciuk, E. Korolczuk (Eds.), Pożegnanie z Matką Polką? Dyskursy, praktyki i reprezentacje macierzyństwa we współczesnej Polsce (pp. 27-49). Warsaw University Press.

Titkow, A., Duch-Krzystoszek, D., \& Budrowska, B. (2004). Nieodpłatna praca kobiet: Mity, realia, perspektywy. Wydawnictwo IFIS PAN.

Wallbank, J. (2018). Challenging Motherhood(s). Routledge.

Yoong, A., \& Koritsas, S. (2012). The impact of caring for adults with intellectual disability on the quality of life of parents. Journal of Intellectual Disability Research, 56(6), 609-619. https://doi.org/10.1111/j.1365-2788.2011.01501.x

Zhu, A. (2016). Maternal Employment Trajectories and Caring for an Infant or Toddler with a Disability. SSRN Electronic Journal. https://doi.org/10.2139/ssrn.2734484 